\title{
Transverse mini skin incision for carpal tunnel release
}

\section{Transvers küçüik cillt kesisiyle karpal tünel serbestleştirilmesi}

\author{
Densel Araç ${ }^{1}$, Hüiseyin Bozkurt² ${ }^{2}$,Bilge Öztoprak ${ }^{3}$
}

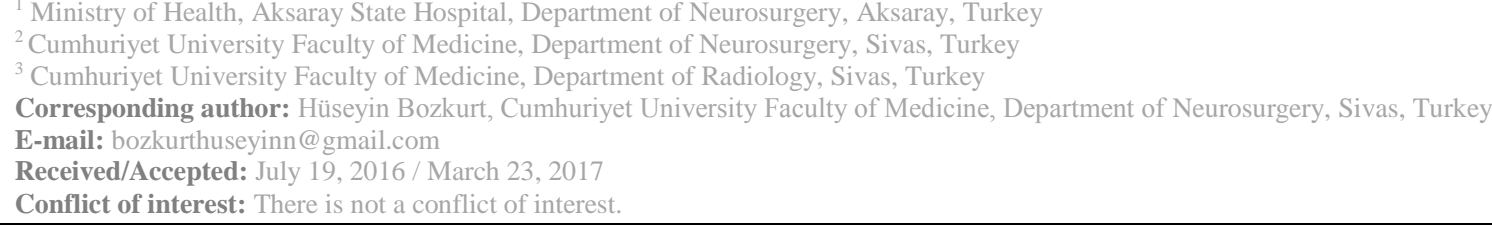

\section{SUMMARY}

Objective: Mini skin incision technique for median nerve release have become popular recently for the treatment of carpal tunnel syndrome. The main advantages of this technique are shorter recovery time and better cosmetic results. Neurovascular injury still remains controversial. We presented the advantages, disadvantages and results of transverse mini skin incision technique to release carpal tunnel syndrome.

Method: 62 carpal tunnel releasing procedures were performed.52 female and 10 male patients with mean age of 62 (ranging from 38 to 82 ) included in this study. All patients were operated by using transverse mini skin incision technique. Results: Significant improvement was observed in symptoms and signs during the postoperative follow-up period. No recurrence or injury to the neurovascular structures was noted.

Conclusions: The technique is simple and effective. Without using expensive instruments better cosmetic results and better recovery time can be achieved.

Keywords : Carpal tunnel syndrome, transverse mini skin incision, better cosmetic results

\section{ÖZET}

Amaç: Karpal tünel sendromu cerrahisinde mini cilt insizyonu tekniği popülerleşmektedir. Tekniğin ana avantajı kısa iyileşme zamanı ve daha iyi kozmetik sonuçtur. Nörovasküler zedelenme ihtimali mini cilt insizyonu tekniğinde hala tartışma konusudur. Makalemizde transvers mini cilt insizyonu tekniğini karpal tünel sendromu cerrahisindeki avantaj ve dezavantajları açısından tartıștık

Yöntem: 62 karpal tünel cerrahisi mini cilt insizyonu ile uygulandı. Hastaların 52 si kadın 10 u erkek idi. Ortalama yaș 62 (en küçük 38 en büyük 82) olarak izlendi.

Bulgular: Takipte hastaların bulgu ve şikayetlerinde belirgin iyileşme izlendi. Hastaların hiç birinde rekürrens veya nörovasküler yapılarda zedelenme izlenmedi.

Sonuç: Mini cilt insizyonu tekniği etkili, basit ve cerrahi için pahalı ekipman gerektirmiyor. Cerrahi sonrası iz ve iyileșme zamanında konvansyonel yönteme nazaran daha iyi sonuçlar veriyor.

Anahtar sözcükler: Karpal tünel sendromu, mini cilt insizyonu, iyi kozmetik sonuç 


\section{INTRODUCTION}

Carpal tunnel syndrome (CTS) is the most common compressive neuropathy, and the median nerve decompression surgery in the carpal region is the most frequent peripheral nerve surgery ${ }^{1-3}$.

The carpal tunnel syndrome results in symptoms of dysesthesia and burning pain in the hand and it mainly affects middle-aged female population ${ }^{3-7}$. History, physical examination, electrophysiological studies and ultrasonography are performed for the diagnosis of carpal tunnel syndrome $^{8-10}$. Surgical treatment is generally recommended in cases who fail to respond conservative treatment including non-steroid antiinflammatory drugs, vitamin B6, local steroid injections, and hand braces ${ }^{2,8,11}$. A variety of surgical techniques have been described for the treatment of carpal tunnel syndrome. The first open carpal tunnel release was performed in 1924 by Mackinnon et al. in Mayo Clinic and popularized later by Phalen et al. ${ }^{12}$.

Major textbooks of hand surgery, peripheral nerve surgery and operative neurosurgical techniques recommend a traditional open-incision technique with longitudinal incision crossing the wrist flexion skin crease as a highly effective approach in the treatment of carpal tunnel syndrome. However, this procedure has many complications including pillar pain, scar tenderness, cosmetic problems, loss of grip and pinch strength or time loss due to inability to work $^{4,8,13,14}$.

Recent studies aim to decrease these complications by mini-open incisions and endoscopic release techniques. Anatomical studies showed that an endoscopic carpal tunnel release does not allow an adequate exploration of thenar branch of the median nerve and decompression of its transligamentous variation ${ }^{15}$. An endoscopic technique also endangers the ulnar and median nerves, branches of the median nerve, and communication between the two nerves both in the carpal tunnel and in the distal forearm ${ }^{16,17}$.

In this study, we aim to describe the surgical technique of median nerve release using single mini skin incision and evaluate the wound healing, cosmetic results, and scar formation on the wrist.

\section{MATERIAL AND METHODS}

This retrospective study was approved by the local ethics committee. All patients and their families had been informed about the operation technique before the operation and have given written informed consent for the procedure.

Between 2012 and 2016, 62 carpal tunnel releasing procedures were performed. The study included 52 female and 10 male patients with a mean age of 62 (ranging from 38 to 82), who were followed up for a mean period of 3 months.

Diagnosis was based on the history of hand dysesthesia, numbness in the median nerve distribution, a positive Phalen's flexion test and/or a positive Tinel's sign and the presence of the classical triad of CTS on ultrasonography, which is palmar bowing of the flexor retinaculum, enlargement of the nerve proximal to the flexor retinaculum, and distal flattening of the nerve. Finally, the patients had positive electromyelographic findings. Pain was measured using Visual Analog Scale (VAS, a scale of 0-10) before and after the procedure. Incision scar hypersensitivity and cosmetic results were evaluated postoperatively with the Visual Analog Patient Satisfaction Scale (VAPSS).

\section{SURGICAL TECHNIQUE}

Before surgery, the forearm, the wrist and the hand were cleaned with povidone iodine solution (Isosol $1000 \mathrm{ml}$, Merkez Laboratory, İstanbul, Turkey). Then surgical incision line was drawn with a sterile surgical pen. The area to be operated was covered with a sterile compress. Local anesthesia was performed with $2 \%$ prilocaine hydrochloride (Citanest $20 \mathrm{ml}$, Flacon Astra Zeneca, İstanbul, Turkey). The hand was positioned in extension. A $1 \mathrm{~cm}$-long transverse incision was performed with no. 15 blade at the wrist region, on the distal flexion crease between the third and fourth fingers (Figure $1)$. 

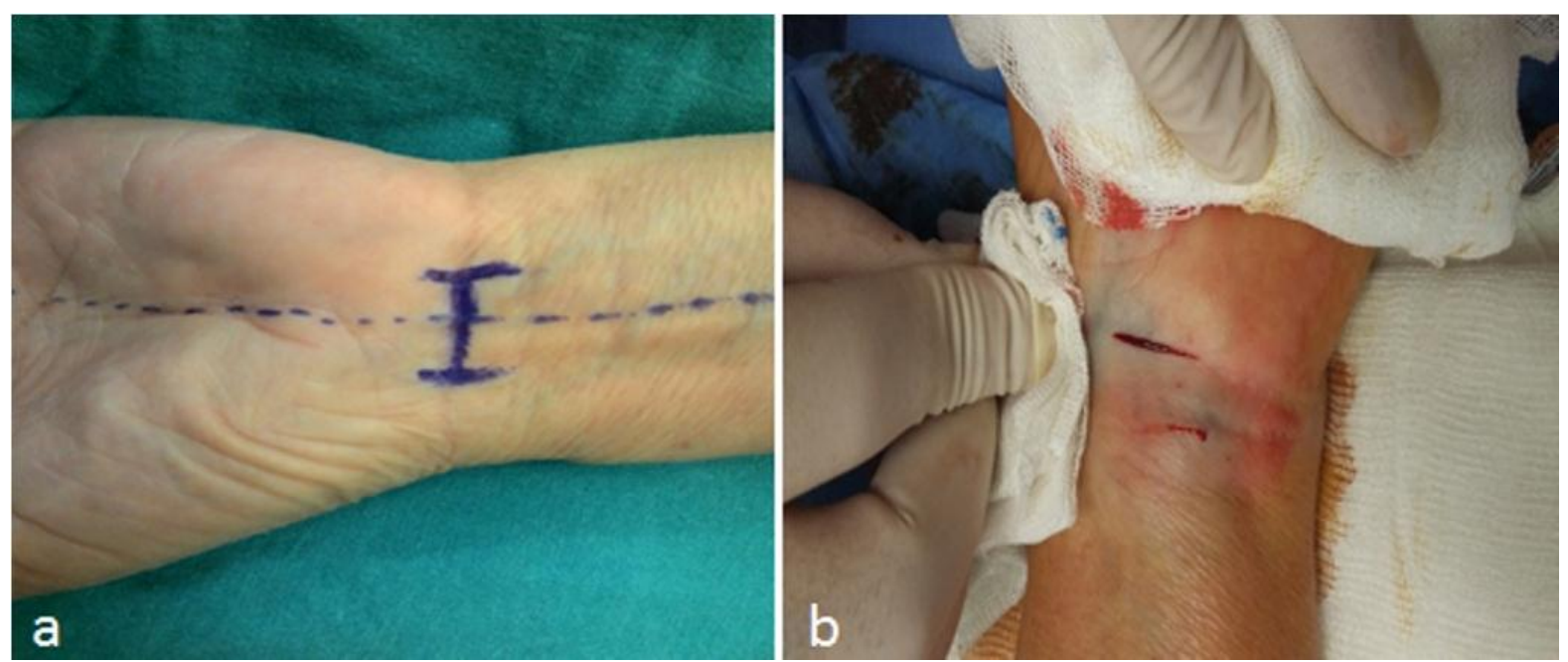

Figure 1. After proper surgical site antisepsis, incision lines were drawn (a) and a transverse incision of about $1 \mathrm{~cm}$ was made on the distal flexion crease (b).

After the skin incision, two retractors were positioned to separate the edges of the incision. The superficial part of carpal ligament was passed with

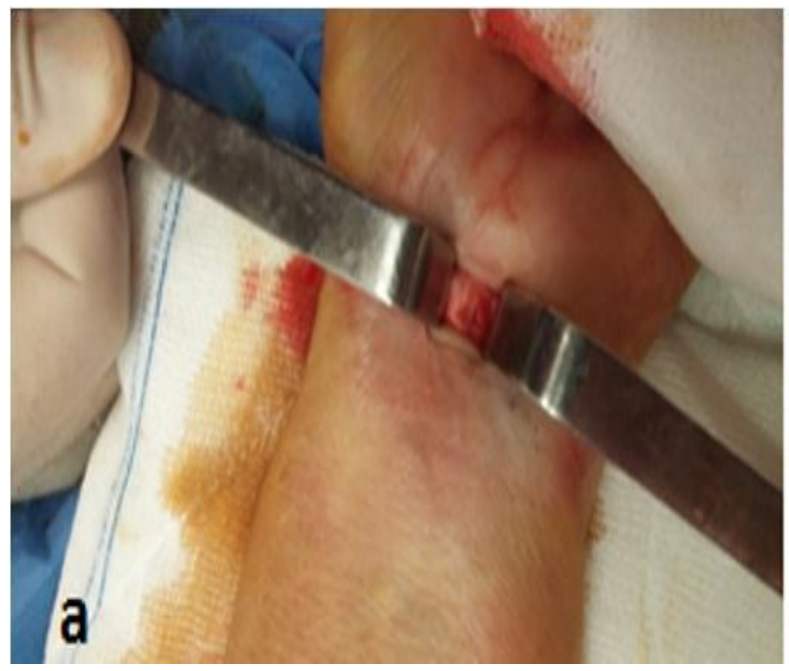

blunt dissection, and then proximal and distal parts of the ligament were cut with scissors to release the median nerve (Figure 2).

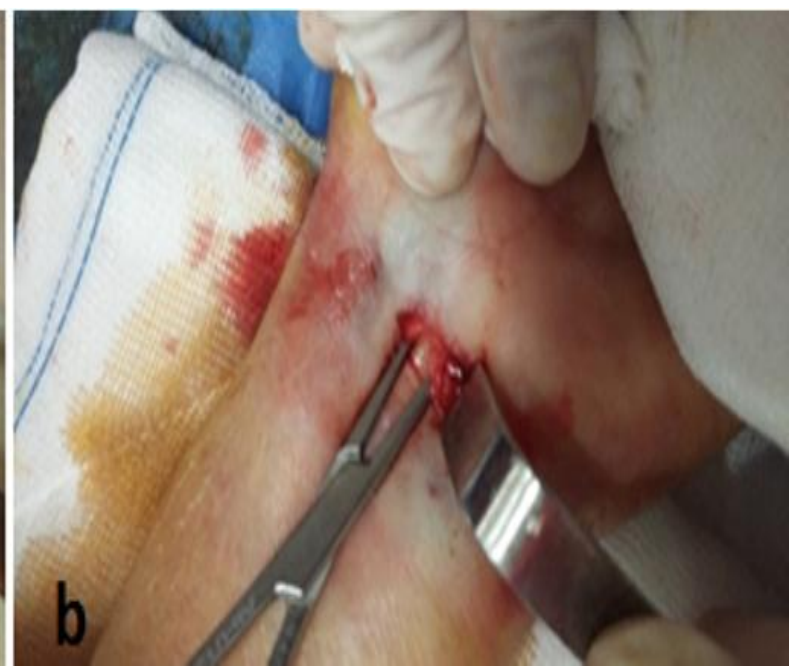

Figure 2. The edges of the incision were separated by two retractors (a) and carpal ligament were cut with scissor.

After irrigation and hemostasis, the skin was closed with 4/0 vicryl sutures, and subcutaneous tissue

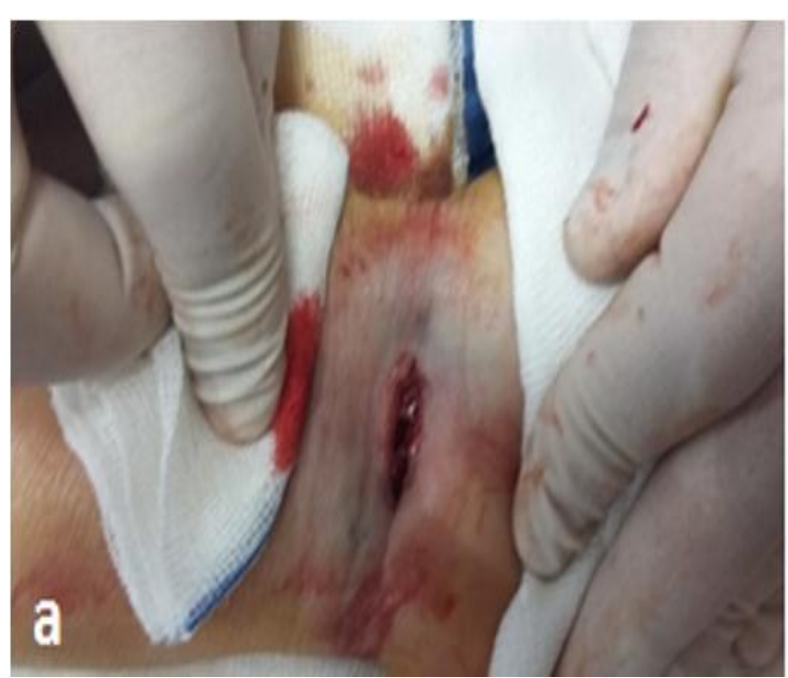

was not sutured (Figure3). The skin sutures were removed 10 days after the operation.

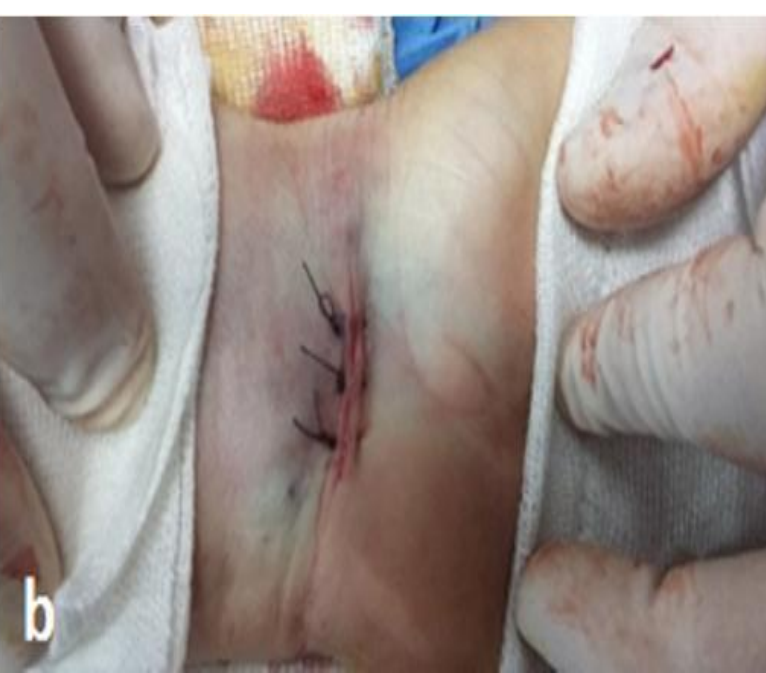

Figure 3. Hemostasis was achieved (a) and the skin was closed, without suturing the subcutaneous tissue (b). 


\section{RESULTS}

All of the 62 (10 male and 52 female) patients included in the study were operated using mini skin incision technique for carpal tunnel release. After the diagnosis of CTS, three of the patients who had a history of wrist fracture were also examined by wrist computerized tomography (CT) for the presence of callus formation in the wrist region. No callus formation was observed on the CT images. Symptoms of patients with CTS were pain, and paresthesia in the distribution of the median nerve. The pain was more intense at night or after specific activities.
There had been no complications during the operations such as bleeding or nerve injury. The mean follow-up period was 3 months. There were no operation-related complications such as skin infection and palmar tenderness. The mean preoperation VAS score for pain was 7.8 which decreased to 2.6 post-operatively. Regarding the scar hypersensitivity and cosmetic results, the mean VAPSS score was 8.5 during the follow-up period (Figure 4). 10 patients had temporary paresthesia and no patients were re-operated.

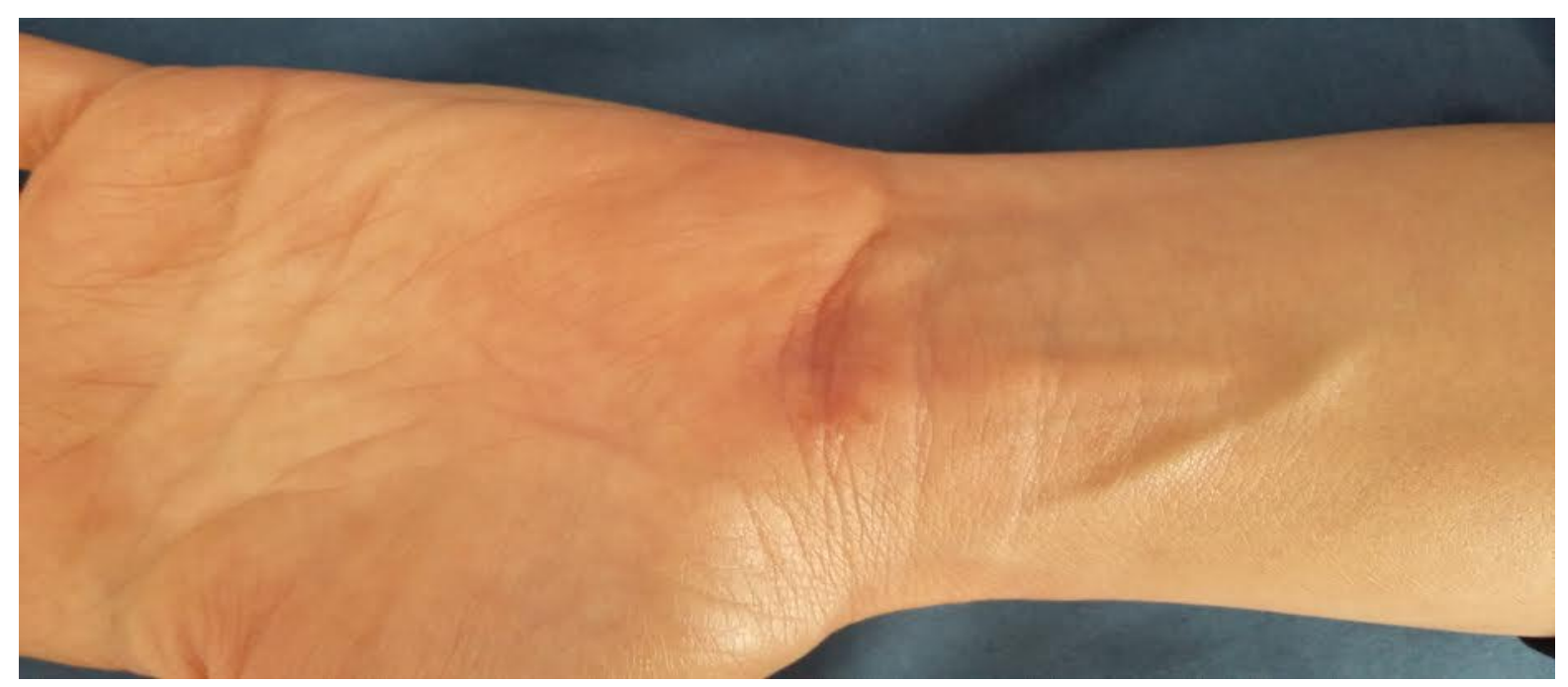

Figure 4. Excellent cosmetic appearance was achieved with mini incision median nerve release. The incision scar is hardly visible since it is superimposed to the distal flexion crease.

\section{DISCUSSION}

This study showed that mini incision technique for median nerve release was effective with low complication rate and high cosmetic outcome. Open carpal ligament transection for median nerve release for the surgical treatment of CTS can be performed through various skin incisions of the palm ${ }^{9,18-26}$. Classical technique has been found to be safe and effective as reported by authors and has rare early complications such as incomplete release of carpal ligament, injury to the palmar cutaneous and recurrent motor branch of median nerve or injury to the superficial palmar arch and ulnar artery, since the operation is performed under direct vision ${ }^{4,8,27}$. However, late complications have a relatively high incidence. These are hypertrophic scar formation, scar tenderness, pillar pain, loss of grip strength and sympathetic dystrophy resulting in the delay of returning to daily activities or work and emotional distress $^{4,8,9,28}$. As many as $24 \%$ of post-operative problems in median nerve release is related to skin incision $^{3}$. Lee and Strickland $^{29}$ reported very promising results of limited palmar incision technique in a series of 525 patients. Limited skin incision is mainly targeted to achieve lesser scar formation, better cosmetic results, and decreased postoperative pain on the surface of palm ${ }^{22,24-26,29-}$ ${ }^{36}$. These goals are substantially reached with mini skin incision technique used in this study.

Endoscopic carpal tunnel surgery has been used to decompress the median nerve in patients with CTS for the past two decades ${ }^{32,33,37}$. No meaningful differences have been reported between the open and endoscopic techniques in the aspects of operating time and cost of surgery ${ }^{33,34}$. The advantage of the endoscopic technique is reduced scar formation on the palmar surface of the hand $^{32,33}$. On the other hand, the endoscopic techniques have some disadvantages such as high complication and recurrence rates ${ }^{37}$.

In this study, we aimed to analyze the outcome of patients operated for carpal tunnel syndrome using limited mini transverse skin incision. This $1 \mathrm{~cm}$ transverse incision is performed at the distal wrist flexion crease where the skin is thinner than the palmar surface. Therefore, complications including 
cosmetic problems, palmar tenderness and scar sensitivity are expected to be less. In this study, we did not see any operation-related complications such as skin infection and palmar tenderness. The mean VAS score for pain was decreased from 7,8 to 2,6 post-operatively and the mean VAPSS score was 8,5 during the follow-up period.

Previous studies reported that either the recurrent thenar branch or palmar arteries have a potential risk of injury during all endoscopic and limited incision techniques ${ }^{10}$. The recurrent thenar branch may leave the median nerve from various anatomic places. These variations may cause difficulties for the surgeon to release or protect the recurrent thenar branch. The palmar arteries, especially superficial arch, also have a potential risk due to the difficulties in visualization with these limited incision or endoscopic techniques. We did not experience any artery, nerve or tendon injuries. Regarding these complications, however, it remains to be studied on larger cohorts to be safely concluded that this technique has comparable results to classical longitudinal release operation.

\section{CONCLUSION}

The limited mini skin transverse incision technique for carpal tunnel release is a safe and effective surgical procedure. This procedure could be used in the surgical treatment of CTS to achieve better palmar appearance and better cosmetic results, and to reduce the complications seen with other standard techniques for median nerve release.

\section{REFERENCES}

1. Eversman WW. Entrapment and compression neuropathies. In: Green DP, editor. Operative hand surgery. New York (NY): Churchill Livingstone; 1998: 1423-78.

2. Gelberman HR. Carpal tunnel release. In: Gelberman RH, North ER, editors. Operative nerve repair and reconstruction. 2 vol. Philadephia (PA): JB Lippincott; 1991. p. 90011.

3. Young HA. Surgical management of peripheral entrapment neuropathy. In: Schmidek HH, Sweet WH, editors. Operative neurosurgical techniques. Indications, methods, and results. Philadephia (PA): WB Saunders, 1988: 1583-98.

4. Açıköz B: Karpal Tünel Sendromu. TND Spinal ve Periferik Sinir Cerrahisi Grubu Yayınları: Periferik Sinir Cerrahisi Demircan N, Zileli M (ed). Ankara: Türk Nöroşirürji Derneği, 2008, 281-304.

5. Brown RA, Helbernan RH, Seiler JG, Abrahamsson SO, Weiland AJ, Urbaniac JR,
Schoenfeld DA, Furcolo D. Carpal Tunnel release: a prospective randomized assessment of open and endoscopic methods. J Bone Joint Surg 1993; 75: 1265.

6. Sever C, Kulahc1 Y, Oksuz S, Sahin C. The mini incision technique for Carpal Tunnel decompression using nasal instruments. Turkish Neurosurg 2010; 20: 353-57.

7. Uygur F, Sever C, Yüksel F. Comparing the results of limited incision technique and standart longitudinal incision tecnique for carpal tunnel decompression by numerical grading system. Turkish Neurosurgery 2009; 19: 51-7.

8. Aroori S, Spence RAJ. Carpal Tunnel Syndrome. Ulster Med J 2008, 77: 6-17

9. Aydın K, Cokluk C, Cengiz N, Bilgici A: Microsurgical open mini uniskin incision technique in the surgical treatment of Carpal Tunnel Syndrome. Neurology India 2006; 54 : 64-7.

10. Aydın K, Cokluk C, Piskin A, Kocabıçak E: Ultrosonographically checking the sectioning of the transverse carpal ligament during Carpal Tunnel Surgery with limited uni skin incisions.Turkish Neurosurgery 2007; 17: 21923.

11. Huisstede, BM, Randsdorp, MS, Coert, JH, Glerum, S, van Middelkoop $M$, Koes BW. Carpal tunnel syndrome. Part II: effectiveness of surgical treatments-a systematic review. Arch Phys Med Rehabil 2010; 91: 1005-24.

12. Phalen GS. The carpal tunnel syndrome. seventeen years' experience in diagnosis and treatment of 654 hands. J Bone Joint Surg Am 1966; 48: 211-28.

13. Einhorn N, Leddy JP. Pitfalls of endoscopic carpal tunnel release. Orthop Clin North Am 1996; 27: 373-80.

14. Lida J, Hirabayashi H, Nakase H, Sakaki T: Carpal Tunnel Syndrome: Electrophysiological grading and surgical results by minimum incision open carpal tunnel release. Neurol Med Chir (Tokyo) 2008; 48: 554-9.

15. Stancic MF, Eskinja N, Stosic A. Anatomical variations of the median nerve in the carpal tunnel. Int Orthop 1995; 19: 30-34.

16. Stancic MF, Micovic V, Potocnjak M. The anatomy of the Berrettini branch: implications for carpal tunnel release. J Neurosurg 1999; 91: 1027-30.

17. Shinya K, Lanzetta M, Conolly WB. Risk and complications in endoscopic carpal tunnel release. J Hand Surg (Br) 1995; 20: 222-7. 
18. Palmer AK, Toivonen DA. Complications of endoscopic and open carpal tunnel release. $\mathrm{J}$ Hand Surg (Am) 1999; 24: 561-5.

19. Ferdinand RD, MacLean JG: Endoscopic versus open carpal tunnel release in bilateral carpal tunnel syndrome. A prospective, randomised, blinded assessment. J Bone Joint Surg Br 2002; 84: 375-9.

20. Nath RK, Mackinnon SE, Weeks PM. Ulnar nerve transection as a comolication of twoportal endoscopic carpal tunnel release: a case report . J Hand Surg (Am) 1993; 18: 896-8.

21. Stancic MF, Burgic N, Micovic V. Marinacci comminication. Case report. J Neurosurg 92: 860-2, 2000

22. Biyani A, Downes EM: An open twin incision technique of carpal tunnel decompression with reduced incidence of scar tenderness. J Hand Surg (Br) 1993; 18: 331-4.

23. del Pinal F, Cruz-Camara A, Jado E. Total ulnar nerve transection during endoscopic carpal tunnel release. Arthroscopy 1997; 13: 235-7.

24. Serra JM, Benito JR, Monner J: Carpal tunnel release with short incision. Plast Reconstr Surg 1997; 99: 129-35.

25. Wilson KM: Double incision open technique for carpal tunnel release: an alternative to endoscopic release. J Hand Surg (Am) 1994; 19: 907-12.

26. Zimmerli W: Double incision for operation of carpal tunnel syndrome- 14 years experience. Helv Chir Acta 1992; 58: 395-400.

27. Badger SA, O'Donnel ME, Sherigor JM, Conolly P, Spence RA: Open Carpal Tunnel release, still safe and effective operation. Ulster Med J 2008; 77: 22-4.

28. Franzini A, Broggi G, Servello D, Dones I, Pluchino MG: Transilluminationin minimally invasive surgery for Carpal Tunnel release. Technical note. J Neurosurg 1996; 85: 1184-6.

29. Lee WP, Strickland JW. Safe carpal tunnel release via alimited palmar incision. Plast Reconstr Surg 1998; 101: 418-26.

30. Vanni D, Sirabella FS, Galzio R, Salini V, Magliani V. The double tunnels technique: an alternative minimally invazive approach for carpal tunnel syndrome. J Neurosurg 2015; 123: 1230-37.

31. Zhang X, Huang X, Wang X, Wen S, Sun J, Shao X: A randomized comparison od double small, standard and endoscopic approaches for carpal tunnel release. Plast Reconstr Surg 2016 doi:10.1097/PRS.0000000000002511

32. Concannon MJ, Brownfield ML, Puckett CL. The incidence of recurrence after endoscopic carpal tunnel release. Plast Reconstr Surg 2000; 105:1662-5.

33. Filippi R, Reisch R, El-Shki D, Grunert P: Uniportal endoscopic surgery of carpal tunnel syndrome: technique and clinical results. Minim Invasive Neurosurg 2002; 45: 78-83.

34. Trumble TE, Diao E, Abrams RA, GilbertAnderson MM. Single - portal endoscopic carpal tunnel release compared with open release: a prospective, randomized trial. J Bone Joint Surg Am 2002; 84-A: 1107-15.

35. Abdullah AF, WolberPH, Ditto EW: Squela of Carpal Tunnel surgery: Rationale for design of a surgical approach. Neurosurgery 1995; 37: 931-6.

36. Nathan PA: Carpal tunnel release using minimally invasive technique.Plast Reconstr Surg 1997; 99: 1195-6.

37. Schmidt W, Gruber AA, Hammer R: Results of different incisions in treatment of carpal tunnel syndrome. Handchir Mikrochir Plast Chir 2000; 32: 67-9. 